\title{
Flow-mediated feeding in the field: consequences for the performance and abundance of a sessile marine invertebrate
}

\author{
Katie K. Arkema ${ }^{1,2, *}$ \\ ${ }^{1}$ Department of Ecology, Evolution and Marine Biology, University of California, Santa Barbara, California 93106, USA \\ ${ }^{2}$ Present address: Woods Institute for the Environment, Stanford University, 2725 Montlake Blvd E., Seattle, \\ Washington 98122, USA
}

\begin{abstract}
The ecology of sessile marine invertebrates that feed on waterborne particles is closely related to their surrounding fluid environment. However, few studies have quantified how water flow affects the feeding success of such organisms under field conditions and whether the results of shortterm feeding assays can predict longer-term patterns of growth and reproduction. I examined the influence of natural variation in current speed on the feeding success, colony growth rate and population abundance of an encrusting bryozoan Membranipora serrilamella using transplant experiments at nearshore reefs along the coast of Santa Barbara, California, USA. Feeding success was highest at intermediate ambient flow speeds $\left(10\right.$ to $\left.12 \mathrm{~cm} \mathrm{~s}^{-1}\right)$ and lowest at low $\left(0\right.$ to $\left.5 \mathrm{~cm} \mathrm{~s}^{-1}\right)$ and fast $\left(>20 \mathrm{~cm} \mathrm{~s}^{-1}\right)$ speeds. Growth rates varied such that the greatest increases in bryozoan colony size occurred at reefs where average temperatures were the coolest and current speeds were intermediate. A test of the hypothesis that high feeding success translates into faster growth rates revealed that colonies with the highest predicted consumption grew the most. Further, spatial variation in $M$. serrilamella abundance mirrored that of colony growth, as percent cover of the bryozoan was highest at reefs where ambient current speeds were intermediate. These nonlinear functional relationships likely result from reductions in food delivery at low flows and deformation of feeding structures at high flows. The consequences of dynamic flow conditions for both short-term and integrated measures of performance suggest that flow-mediated food acquisition plays an important role in determining the distribution, abundance and morphology of encrusting bryozoans and other sessile, suspension-feeding invertebrates.
\end{abstract}

KEY WORDS: Membranipora serrilamella $\cdot$ Suspension feeding $\cdot$ Current speed $\cdot$ Specific growth rate $\cdot$ Sessile $\cdot$ Particle capture $\cdot$ Unimodal feeding response

\section{INTRODUCTION}

The need to acquire resources places significant ecological and evolutionary constraints on animals and plants. Ideal conditions for resource acquisition may be influenced by behavioral and morphological traits of organisms (Elner \& Hughes 1978, Kacelnik 1984, LaBarbera 1984), ecological pressures, such as intraand interspecific competition and predation (Fretwell 1972, Holbrook \& Schmitt 1988), or the abiotic environment (Sogard \& Olla 1998, Sears 2005). Mobile animals have the ability to move to alternative locations to avoid unfavorable circumstances for acquiring resources, such as choosing to forage closer to refuges under conditions of higher predation pressure (Milinski \& Heller 1978, Holbrook \& Schmitt 1988). Sessile organisms, however, cannot change locations when circumstances vary and therefore continuously experience the costs and benefits of biotic and abiotic conditions (Denny 1985, Hurd 2000).

In marine ecosystems, resource acquisition by sessile organisms is strongly influenced by the surrounding fluid environment (Denny 1988). Water flow can have both costs and benefits for aquatic species of primary 
producers and consumers. In particular, the relationship between feeding and current speed can be influenced by both the necessity of resource delivery and the exposure to damage from hydrodynamic forces. For example, macrophytes rely on water flow to deliver nutrients, but extreme flow can negatively affect nutrient uptake, light capture and photosynthesis (Hurd 2000).

Optimal conditions of water flow are particularly important to sessile marine invertebrates that feed by filtering suspended particles (Wildish \& Kristmanson 1997). Current speed affects their feeding success by altering the flux of food particles and the efficiency of their feeding structures. Fast flows can deform feeding organs (Sponaugle \& LaBarbera 1991, Eckman \& Duggins 1993) or cause a behavioral response that limits ingestion (Wildish \& Kristmanson 1997 and references within), while slow flows may lead to inadequate food supply (Wildish \& Kristmanson 1997, Sebens et al. 1998). Generally, studies of the relationship between water flow and suspension feeding in marine systems have examined the effects of current speed on growth rates (Kirby-Smith 1972, Lesser et al. 1994, Okamura \& Partridge 1999). A few have tested the effect of water flow on capture rates of particles (typically latex beads). However, with a couple of exceptions (e.g. Sebens et al. 1998), studies on actual food consumption have been limited to the laboratory (e.g. Okamura 1992, reviewed in Wildish \& Kristmanson 1997) because of the logistical challenges of measuring feeding success in situ for many species of suspension feeders. Moreover, implicit in previous investigations of the effect of flow regime on suspension feeders is the assumption that short-term feeding success and integrated fitness measures such as growth or reproduction are correlated. Few studies have quantitatively investigated the relationship between flow-mediated feeding and variation in growth or reproduction (for qualitative comparisons see Okamura 1992, Riisgård \& Goldson 1997, Pratt 2008). Because natural conditions of water flow can vary dramatically over short temporal scales of minutes to hours (Gaylord et al. 2007), the degree to which short-term feeding by sessile marine invertebrates leads to variation in comparatively longer term measures of individual performance or population attributes is not generally demonstrated.

The present study considers the influence of natural variation in water flow on the feeding success, growth rate and abundance of a member of a cosmopolitan genus of encrusting bryozoan, Membranipora serrilamella. Understanding the feeding and growth response of Membranipora spp. to water flow is important, as encrusting bryozoans have proven to be formidable invasive species (Levin et al. 2002) and can have significant positive and negative effects on the kelps that serve as their living substrate (Hepburn et al. 2006 and references therein). Through field experiments and observations, I determined the nature of the relationship between variation in ambient current speed and in situ feeding success, explored the effect of spatial and temporal variation in ambient current speed on colony growth rate, tested the hypothesis that feeding success and growth rate are correlated and assessed spatial patterns of variation in abundance of $M$. serrilamella in relation to water flow.

\section{MATERIALS AND METHODS}

Study sites and study organism. The present study was carried out at 5 sites along the coast of Santa Barbara, California, USA. From west to east, the sites were Arroyo Quemado (AQUE, $34^{\circ} 27.897^{\prime} \mathrm{N}, 120^{\circ} 07.179^{\prime} \mathrm{W}$ ), Naples (NAPL, 34 $25.433^{\prime} \mathrm{N}, 119^{\circ} 57.019^{\prime} \mathrm{W}$ ), Mohawk Offshore (MOKO, 34 ${ }^{\circ} 25.590^{\prime} \mathrm{N}, 119^{\circ} 43.791^{\prime} \mathrm{W}$ ), Mohawk Inshore (MOKI, $34^{\circ} 23.639^{\prime} \mathrm{N}, 119^{\circ} 43.750^{\prime} \mathrm{W}$ ) and Carpinteria (CARP, 34 $23.409^{\prime} \mathrm{N}, 1^{\circ} 119^{\circ} 32.394^{\prime} \mathrm{W}$ ). These locations were chosen to represent a range of current speeds that occur in the Santa Barbara Channel. At depths of 7 to $15 \mathrm{~m}$, the study sites were in soft bottom habitat approximately 20 to $40 \mathrm{~m}$ offshore from rocky reefs that typically support underwater forests of giant kelp Macrocystis pyrifera.

In southern California, Membranipora spp. is one of the most abundant epiphytes on giant kelp, primarily forming encrusting colonies on the wide blades of its host. Several studies suggest that Membranipora spp. along the west coast of North America (i.e. M. membranacea, $M$. villosa and $M$. serrilamella) are alternative morphologies of the same species (Yoshioka 1982, Schwaninger 1999, Dick et al. 2005). Here I refer to the study species as $M$. serrilamella because of the characteristic crypocyst (inner extension of zooid wall) identified in the samples (Schwaninger 1999 and references therein). However, the focal species in the present study may be functionally indistinct from those described as M. membranacea and M. villosa in previous studies of flow-mediated feeding, growth, morphology and abundance.

Each Membranipora serrilamella colony consists of semi-autonomous units (zooids) that are capable of feeding and reproducing sexually and asexually. An active suspension feeder, $M$. serrilamella uses its ciliated, tentacular lophophores to induce water currents from which it filters phytoplankton (Fig. A1a in Appendix 1). Many studies have investigated the response of Membranipora spp. and other encrusting bryozoans to variation in flow, yet the results have been largely inconsistent. Feeding responses to flow have been positive (Pratt 2004), negative (Okamura 1992) and unimodal (Pratt 2008), and growth responses have been 
positive linear (Grünbaum 1997), negative linear (Eckman \& Duggins 1993) and nonexistent (Okamura \& Partridge 1999). Part of the problem may be that previous research generally assessed feeding over a narrow range of flow velocities (but see Pratt 2008) or measured flow during just a fraction of the growth period (e.g. Okamura \& Partridge 1999, Pratt 2008). These approaches did not account for the full distribution of current speeds that suspension feeders are exposed to in their natural environment. In the present study I determined whether the temporal and spatial variation in current speed that occurs in situ along the Santa Barbara coast (McPhee-Shaw et al. 2007) influences the feeding, growth and abundance of $M$. serrilamella living in nearshore forests of giant kelp.

Current speed and feeding success. I investigated the relationship between feeding success of Membranipora serrilamella and natural variation in water flow by transplanting kelp blades covered in the encrusting bryozoan to the 5 study sites during the summers of 2005 and 2006 and measuring feeding success under different conditions of current speed. Feeding success was measured in situ using a gut pigment content (GPC) approach that I developed based on methods for quantifying feeding by zooplankton (Mackas \& Bohrer 1976, Dagg \& Walser 1987). The approach involved collecting samples of bryozoan colonies, separating the colonies from the giant kelp blades, dissolving the exoskeleton of the colony and measuring the amount of phytoplankton-derived pigments in the guts of the zooids (see below). GPC was determined by summing chlorophyll a (chl a) and the chlorophyll degradation products (phaeopigments), which remain unaltered after they are produced in the gut (Dagg \& Walser 1987 and references therein) and thus reflects ingested phytoplankton biomass. Because Membranipora spp. process the food in their guts in approximately $30 \mathrm{~min}$ (Winston 1977), feeding success data in the present study are based on the assumption that the amount of phytopigment measured in the guts was a result of feeding during the previous $30 \mathrm{~min}$. Feeding success data were in turn related to the average current speed that occurred during the previous $30 \mathrm{~min}$ period.

To transplant the colonies, Macrocystis pyrifera blades were randomly collected from kelp forests located at each site and attached to a polypropylene line suspended vertically in the water column with benthic weights and subsurface buoys (Fig. A1b). The blades were collected with $\sim 5 \mathrm{~cm}$ of the stipe remaining on either side of the pneumatocysts and attached using rubber bands that connected the stipe portion to the line, allowing for natural movement with a change in current direction (Fig. A1c). Blades were placed 4 to $6 \mathrm{~m}$ below the surface, a depth at which Membranipora serrilamella colonies commonly occur and where current speed can be measured accurately by flow instrumentation (in this case, Acoustic Doppler Current Profilers [ADCPs]; see below). The polypropylene lines were transplanted outside of the kelp forests to exclude potential effects of aggregations of giant kelp on current speed (Gaylord et al. 2007).

To measure GPC I removed the kelp blades from the polypropylene line and placed them on dry ice within 5 min of collection. After returning to the laboratory, blades were transferred to a $-80 \mathrm{C}^{\circ}$ freezer. Within $1 \mathrm{wk}$ after the collection I scraped 1 sample (approximately $40 \mathrm{~mm}^{2}$ ) from 3 separate colonies on each blade. The scraping procedure was completed in low light conditions and before the blades defrosted so that colonies were removed without puncturing the cuticle of the kelp. I immediately photographed the Membranipora serrilamella samples and later digitally measured the area of each sample using the software program ImageJ. Following methods for measuring the GPC of copepods (Dagg \& Walser 1987, Rodriguez et al. 1991), M. serrilamella gut pigments were extracted in $90 \%$ aqueous acetone, which also dissolved the colony exoskeleton, for approximately $30 \mathrm{~h}$ in the dark. The exoskeleton was further degraded by vortex-mixing the sample for $5 \mathrm{~s}$ twice during the extraction period. The fluorescence of the suspension was measured before and after acidification with $10 \% \mathrm{HCL}$ using a Turner Designs fluorometer (10-AU-005-CE).

GPC of pelagic suspension feeders is generally measured as mass of chl $a$ and phaeopigment per individual (e.g. zooplankton, Dagg \& Walser 1987; or salp, Purcell \& Madin 1991), which would not be appropriate for a colonial animal such as a bryozoan. Instead, I calculated GPC per unit area of colony because Membranipora serrilamella grows in a single encrusting layer of zooids. GPC was calculated as the mean of the samples from the 5 kelp blades collected each time a site was visited. GPC was measured during 16 site visits $(\mathrm{N}=3$ at $\mathrm{MOKO}$ in 2005; $\mathrm{N}=4$ each at MOKO and MOKI in 2006; $\mathrm{N}=2$ each at AQUE and NAPL in 2006; $\mathrm{N}=1$ at CARP in 2006).

To explore the relationship between feeding success and water flow, I determined the mean ambient current speed during the 30 min prior to colony collection for GPC analysis. Ambient water flow was measured at each site using bottom-mounted ADCPs (600 and $1200 \mathrm{kHz}, \mathrm{RD}$ Instruments), which collected a 1 to $4 \mathrm{~min}$ burst of $1 \mathrm{~Hz}$ velocity data every 2 to $8 \mathrm{~min}$ in $0.5 \mathrm{~m}$ vertical bins extending from $1.5 \mathrm{~m}$ above the bottom to $1.5 \mathrm{~m}$ below the surface. Data from all 3 axes were used to calculate current speed, so that mean speed was independent of the direction of flow. The raw time series were smoothed temporally by blockaveraging over 15 min segments. Data from depths of 4 to $6 \mathrm{~m}$ were averaged so that each flow datum repre- 
sented the speed for the depth horizon where the colonies were transplanted.

To determine the shape of the relationship between feeding success and water flow, I used a model selection approach (Burnham \& Anderson 2002; Table A1 in Appendix 1) that evaluated the relative evidence for 3 functional relationships between GPC and current speed. Based on Membranipora serrilamella morphology and results of previous laboratory experiments (Eckman \& Duggins 1993, Wildish \& Kristmanson 1997, Pratt 2008), I hypothesized that the relationship between feeding and flow might be linear, asymptotic or parabolic. I used an iterative algorithm to estimate parameter values for each model (SAS 9.1) and performed model selection using Akaike's information criterion corrected for small sample sizes $\left(\mathrm{AIC}_{\mathrm{c}}\right.$ Burnham \& Anderson 2002; Table A1 in Appendix 1). Finally, I determined the amount of variation in feeding success explained by water flow using the model with the most substantial support, as selected by $\mathrm{AIC}_{\mathrm{C} r}$ and traditional (least-squares) regression analysis.

Current speed and growth. The relationship between feeding success of Membranipora serrilamella and current speed identified in the first set of experiments motivated a second experiment exploring whether natural variation in current speed affected longer term measures of performance of $M$. serrilamella, such as colony growth rate. To examine the relationship between growth and current speed, I measured changes in the size of colonies transplanted to the 5 study sites. Sixty healthy kelp blades colonized with $M$. serrilamella were transplanted to the same locations used in the feeding experiment and colony growth was followed during August 2006 for approximately $1 \mathrm{wk}$, which constitutes a significant portion of the roughly 6 wk lifespan of Membranipora spp. in southern California (Yoshioka 1982). Kelp blades were collected from 2 of the 5 study sites (NAPL and CARP) to minimize the influence of possible among-site differences in colony morphology (Okamura \& Partridge 1999). Thirty blades from NAPL and CARP were transplanted to each of the 5 study sites and attached to lines (randomly with respect to their origin) using the same procedures described for the feeding experiments. One colony on each kelp blade (4 to $15 \mathrm{~mm}$ in diameter) was marked with 2 small punched holes spaced about $30 \mathrm{~mm}$ from the colony edge on 2 sides (Fig. A1d). To ensure that focal colonies were viable, only those with intact growing edges and actively extended lophophores were chosen for the experiment.

At the beginning and end of the experiment, I measured the length of the longest diameter of each marked colony and used these measurements to estimate initial area, the amount of area added to the colony during the experiment, colony specific growth rate and the mean colony specific growth rate at each site. Growth rates of encrusting bryozoans tend to be indeterminate, such that an increase in colony size is positively and linearly related to original size (Harvell et al. 1990). Because the duration of the experiment differed slightly among sites (CARP $=7 \mathrm{~d}$; AQUE, MOKO, MOKI, NAPL $=8 \mathrm{~d}$ ), area added was calculated on a per day basis by dividing final area minus initial area by number of days. The slope $(m)$ of the relationship between area added $\left(\mathrm{d}^{-1}\right)$ and initial area at each site (intercept constrained to 0 ) was used as a measure of the proportional increase in size during the experiment.

The area of encrusting bryozoan colonies increases exponentially as a function of time (Arkema 2008). Thus the specific growth rate $\left(\mathrm{d}^{-1}\right)$ of each Membranipora serrilamella colony was calculated as $\ln \left(N / N_{0}\right) / t$, such that $N$ was the size of the colony at the end of the experiment, $N_{0}$ was the initial size and $t$ was time measured in days. A mean colony specific growth rate was calculated for each site and the influence of site on growth was tested using 1-way ANOVA. Due to the loss of some blades and the potential for overcrowding to affect colony growth (Yoshioka 1982, Harvell et al. 1990), I focused this analysis on a total of 169 colonies from the 5 sites. The data met ANOVA assumptions of normality and variance.

I also measured temperature during the experiment to evaluate its potential effect on specific growth rate and account for that influence in the experiments. Temperature loggers (Stowaway Onset tidbits, accuracy $\pm 0.2^{\circ} \mathrm{C}$ ) were attached to mooring lines at the same depth as the blades. Temperatures were recorded every 2 min and averaged for each 30 min interval during the experiment. Linear regression analysis was used to determine the relationship between mean colony specific growth rate (dependent factor) and mean temperature (independent factor). Because temperature explained a portion of the among-site variation in growth, I adjusted specific growth rate for the influence of temperature before examining its relationship with current speed. One way to do this would have been to simply relate the residuals from the linear regression of specific growth rate by temperature $(\mathrm{N}=$ 5 sites) to current speed. However, this would have resulted in a counter-intuitive presentation where standardized growth at some sites would have been negative. To avoid potential confusion in interpretation, I added the mean specific growth rate among the 5 sites $\left(0.29 \mathrm{~d}^{-1}\right)$ to each of the residuals to make all adjusted growth rates non-negative.

To determine the influence of current speed on colony growth, I compared specific growth rate (adjusted for temperature) to the distribution of current speeds that occurred at each site during the experi- 
ment. The entire distribution of current speeds is more appropriate than a measure of central tendency because flows were measured over much shorter time scales than growth rates (e.g. minutes versus days). I used the relationship between current speed and zooid feeding success derived from the first set of experiments to categorize objectively every 30 min block of flow speeds into one of 5 groups: flows too low for maximal food intake (suboptimal low $=0-5 \mathrm{~cm} \mathrm{~s}^{-1}$ and 5-10 $\mathrm{cm} \mathrm{s}^{-1}$ ), intermediate flows where feeding success was the greatest (optimal $=10-15 \mathrm{~cm} \mathrm{~s}^{-1}$ ) and fast flows that reduced uptake by inhibiting feeding (suboptimal high $=15-20 \mathrm{~cm} \mathrm{~s}^{-1}$ and $>20 \mathrm{~cm} \mathrm{~s}^{-1}$ ). The proportion of time that Membranipora serrilamella were exposed to ideal versus suboptimal current speeds, with respect to zooid feeding success, was calculated and compared to the independently estimated colony specific growth rate for each site.

The growth rate and feeding success of suspension feeders can be influenced by the ambient concentration of food particles, as well as current speed, which affects the delivery of those particles. To control for variation in food concentration (as much as possible in the field), I conducted the growth and feeding success experiments during the same season (summer) in both 2005 and 2006. I chose summer because phytoplankton biomass in the Santa Barbara Channel at this time tends to be consistently low (Otero \& Siegel 2004), which should emphasize any flow-related difference among sites in $M$. serrilamella feeding and growth. To determine whether food concentrations varied among sites I measured ambient chl a using water samples and satellite sensors. Water samples were collected at each site adjacent to the experimental units on 4 days during the 7 to $8 \mathrm{~d}$ growth experiment using $125 \mathrm{ml}$ bottles. The samples were transported to the laboratory in a cooler and filtered (Millipore GF/C filters) within $4 \mathrm{~h}$ of collection. The concentration of chl $\mathrm{a}$ in the water samples was measured using fluorometry (Smith et al. 1981). Chl a concentrations at the sea surface were assessed using satellite sensors (MODIS Aqua). All L2 pixels within $4 \mathrm{~km}$ of the site, excluding land pixels, were sampled (Feldman \& McCain 2007) in daily passes. The satellite data represent a more continuous sampling of chlorophyll, while the spatial accuracy of the bottle data is superior. Two-way ANOVA was used to test for differences in chl a concentration among sites and between methods. I also tested for the potential significance of the interaction term to verify that any statistical differences among sites did not depend on the method. Both site and method were treated as fixed factors. Data were square-root transformed to meet assumptions of normality and homogeneity of variance and to reduce the influence of outliers.
Relationship between in situ feeding success and growth rate. If the effect of water flow on colony specific growth rate was in part driven by variation in food consumption then feeding and growth should be positively related for Membranipora serrilamella. Using the relationship between feeding success and current speed, I calculated the predicted amount of food that should have been consumed during the growth experiment (i.e. consumption) and used multiple regression analyses to examine the amount of variation in specific growth rate explained by the independent variables, consumption and temperature, and to determine the direction of the relationship between each of these variables and specific growth rate. Consumption was calculated as the sum of the amount of phytopigment (GPC) predicted to have been consumed (using the parameters from the equation that best fit the relationship between GPC and current speed) during each $30 \mathrm{~min}$ period of the growth experiment, multiplied by the ambient concentration of chl a at a site as determined from satellite sensors (MODIS Aqua).

Current speed, water temperature and growth were also measured at 2 sites (AQUE and MOKO) during $1 \mathrm{wk}$ in June and $1 \mathrm{wk}$ in August 2007 ( $\mathrm{N}=2$ sites $\times$ 2 mo $=4$ growth periods). These data were combined with the 2006 data ( $N=5$ growth periods) to test the model including both predicted consumption and temperature.

Current speed and abundance. To investigate potential population consequences of the effects of water flow on feeding success and growth rate, I measured Membranipora serrilamella abundance at each site at the end of the growth experiment. I assumed that the initial abundances of $M$. serrilamella on kelp blades transplanted to each site were the same, as I had randomly allocated blades among sites. Because M. serrilamella is colonial, the percentage area of transplanted kelp blades covered by colonies was used as a proxy for population size (i.e. in this case, number of zooids). The presence of the bryozoan was determined at 50 uniformly distributed points in a $10 \times 5 \mathrm{~cm}$ quadrat placed randomly within the center third of each transplanted blade. Percent cover within a quadrat was estimated as the fraction of the 50 points occupied by M. serrilamella multiplied by 100 . The average percent cover of the bryozoan on transplanted blades at each site (AQUE: $\mathrm{N}=50$; MOKO: $\mathrm{N}$ =45; CARP: $\mathrm{N}=47$; MOKI: $\mathrm{N}=50$; NAPL $\mathrm{N}=21$ blades) was compared to the proportion of time that the colonies were exposed to ideal versus poor current speeds (with respect to feeding success) during the growth experiment in order to determine if there was a relationship between flow regime and population size. 
One-way ANOVA was used to assess among site differences in percent cover. Data were arcsine squareroot transformed to meet the assumption that errors were normally distributed. Because the transformation only marginally improved the homogeneity of the site variances in percent cover, I also analyzed the arcsinetransformed data with a Welch test which evaluates equality of groups when variances are different (Quinn $\&$ Keough 2002). Because the p-values for both tests were highly significant, I interpreted the results from the ANOVA and used Tukey's HSD test to make multiple comparisons between the percent cover means at the 5 sites.

\section{RESULTS}

\section{Current speed and feeding success}

The amount of phytopigment in the guts of Membranipora serrilamella zooids ranged from 11.2 to $17.8 \mathrm{ng}$ $\mathrm{mm}^{-2}$ during the 16 site visits. Current speeds also varied from 2.3 to $21.2 \mathrm{~cm} \mathrm{~s}^{-1}$. GPC, a proxy for feeding success, was highest at intermediate current speeds and lowest at low and high current speeds (Fig. 1). Variation in feeding success was considerably better explained by the parabolic model than the linear or saturating models; the parabolic model had the lowest $\mathrm{AIC}_{\mathrm{C}}$ value and the Akaike weight closest to 1 (0.71), indicating high model selection confidence (Table A1). Using the negative parabolic function, current speed explained $43 \%$ of the variation in GPC $(y=12.8+0.48 x$ $\left.-0.05(x-7.04)^{2} ; \mathrm{N}=16, \mathrm{r}^{2}=0.43, F_{2,13}=4.9, \mathrm{p}<0.03\right)$. GPC increased with current speeds up to $12 \mathrm{~cm} \mathrm{~s}^{-1}$ before declining.

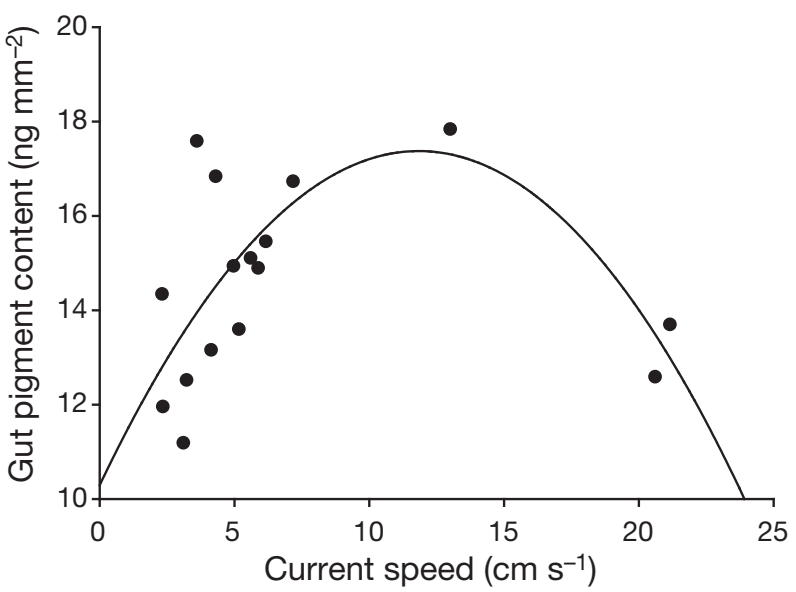

Fig. 1. Membranipora serrilamella. Feeding success in relation to water flow. Each point is the mean gut pigment content during a site visit ( $\mathrm{N}=5$ kelp blades sampled) and the mean current speed during the 30 min prior to colony collection $(\mathrm{N}=2$ periods of $15 \mathrm{~min})$

\section{Variation in abiotic and biotic conditions between growth experiment sites}

Current speeds varied dramatically in space and time during the growth experiment (Fig. 2a). The site with the highest median $\left(23.7 \mathrm{~cm} \mathrm{~s}^{-1}\right)$ and most variable water flow was NAPL, where $50 \%$ of the time current speeds were between 16 and $28 \mathrm{~cm} \mathrm{~s}^{-1}$ (Fig. 2a). Water flow at MOKO (median $=11.8 \mathrm{~cm} \mathrm{~s}^{-1}$ ) was slower than at NAPL but also highly variable (50\% of the time between 6 and $19 \mathrm{~cm} \mathrm{~s}^{-1}$; Fig. 2a). The median speed at AQUE was slower $\left(7.2 \mathrm{~cm} \mathrm{~s}^{-1}\right)$ and water flow less variable ( $50 \%$ of the time between 5 and $10 \mathrm{~cm} \mathrm{~s}^{-1}$ ) than at NAPL and MOKO. Current speeds were substantially slower at CARP and MOKI (median = 4.1 and $2.8 \mathrm{~cm} \mathrm{~s}^{-1}$, respectively) and less variable (Fig. 2a).

Water column temperatures also differed among the 5 sites (but less than site differences in current speed) during the growth experiment (Fig. 2b). The mean temperature at the coolest site, NAPL, was about $1.5^{\circ} \mathrm{C}$ cooler than the mean temperature at MOKI, the warmest site. Temperature extremes ranged from as
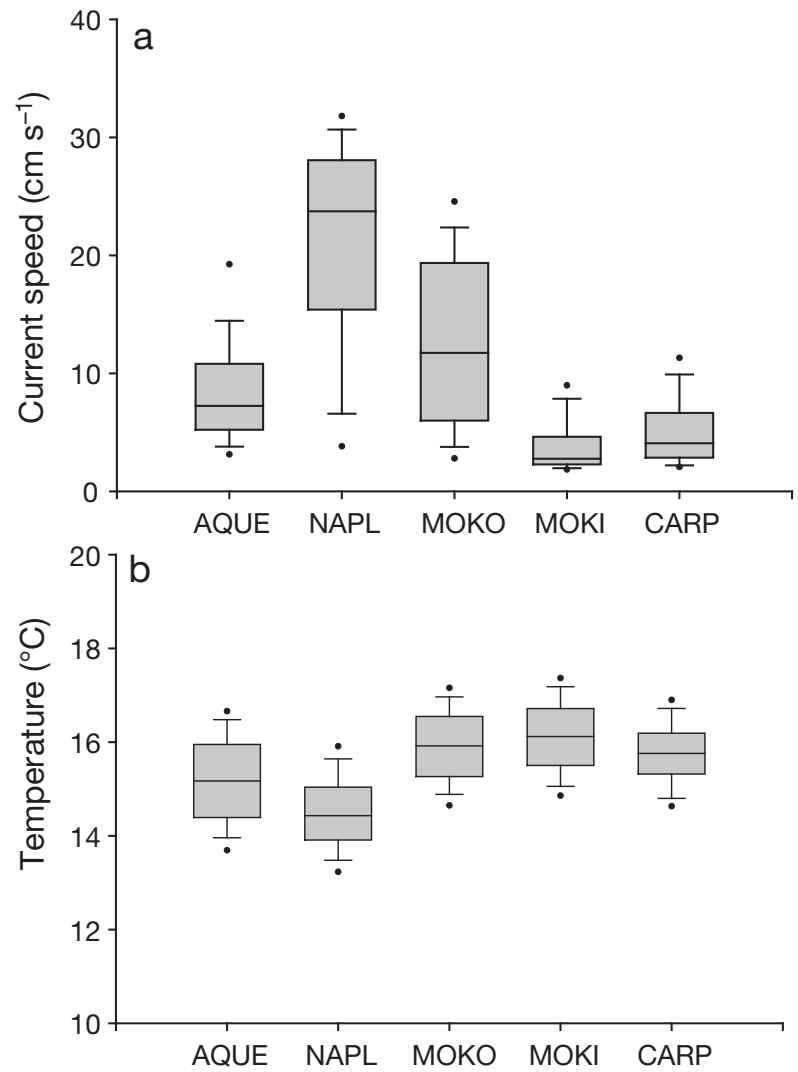

Fig. 2. Box-plots showing median (a) current speed and (b) water temperature at each site during the growth experiment. Also shown are the 10th, 25th, 75th, and 90th percentiles; dots indicate the 5th and 95th percentiles. AQUE: Arroyo Quemado; NAPL: Naples; MOKO: Mohawk Offshore; MOKI: Mohawk Inshore; CARP: Carpinteria 
low as $13.1^{\circ} \mathrm{C}$ at NAPL to $>18.0^{\circ} \mathrm{C}$ at $\mathrm{MOKO}$ and MOKI.

The average concentration of chl $a$ in the water column was comparable among sites and between sampling methods (Fig. 3). Estimates of chl a obtained from water samples and MODIS Aqua satellite data were similar and concentrations did not differ among sites (method $F_{1,44}=2.63, \mathrm{p}>0.1 ;$ site $\left.F_{4,44}=1.0, \mathrm{p}>0.4\right)$. The interaction term (method $\times$ site) was insignificant $\left(F_{4,40}=0.9, \mathrm{p}>0.5\right)$ so the variation was pooled with the residual. Further, estimated chl a values $\left(\sim 1.5 \mu \mathrm{g} \mathrm{l}^{-1}\right)$ were consistently low during the experiments compared to the range of chl a concentrations found at other times of the year at these sites (generally 1 to $6 \mu \mathrm{g} \mathrm{l}^{-1}$ but occasionally up to $20 \mathrm{\mu g} \mathrm{l}^{-1}$; SBC LTER unpubl. data, http://sbc.lternet.edu/data/index.html). Thus food concentration was similarly low at all sites.

\section{Factors influencing colony growth}

Growth of Membranipora serrilamella colonies differed among the 5 study sites. Change in colony area $\left(\mathrm{mm} \mathrm{d}^{-1}\right)$ was positively and linearly related to initial colony size; however, the slope of this relationship varied with site (Fig. 4). Colony specific growth rate differed significantly between sites $\left(F_{4,164}=52.8, \mathrm{p}<\right.$ 0.0001) and although temperature was not a statistically significant predictor of the mean colony specific growth rate at a site (linear regression, $\mathrm{N}=5, F_{1,4}=2.5$, $\mathrm{p}>0.2$ ), it statistically accounted for $46 \%$ of the among-site variation in the growth relationships, with a (non-significant) tendency for fastest growth at the coolest sites ( 0.3 to $0.37 \mathrm{~d}^{-1}$ ). The result of a relatively high $\mathrm{r}^{2}$ value and non-significant $\mathrm{p}$-value was likely

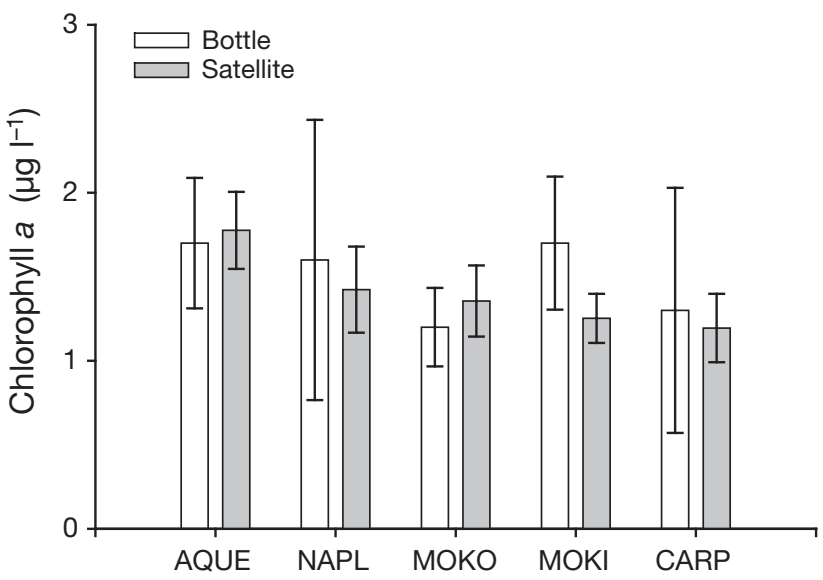

Fig. 3. Food concentration for Membranipora serrilamella at each site during the growth experiment. Data are mean $( \pm \mathrm{SE})$ concentrations of chlorophyll a measured with water samples (bottle, $\mathrm{N}=4$ instantaneous measurements) and satellite sensors ( $\mathrm{N}=6$ day-long passes). See Fig. 2 for site abbreviations due to the limited sample size ( $\mathrm{N}=5$ sites) which resulted in low statistical power. A power analysis indicated that 10 observations were the expected minimum number needed to achieve a significance value of $\mathrm{p}<0.05$ for the observed effect size and standard error.

Specific growth rate, adjusted for the average temperature at each site, varied with the proportion of time that colonies were exposed to different current speeds (Fig. 5). The highest growth rates occurred at MOKO and AQUE, where over $60 \%$ of the time current speeds were within the range of 5 to $20 \mathrm{~cm} \mathrm{~s}^{-1}$, conferring maximal zooid feeding success (Fig. 1). The lowest growth occurred at CARP, NAPL and MOKI, sites characterized by the most extreme high and low flow categories, where zooids had comparatively low feeding success (Fig. 1). These data demonstrate that the relationship between the distribution of current speeds that occurred over a week-long period and standardized specific growth rate (Fig. 5) was quantitatively similar to the negative parabolic relationship observed between current speed and a comparatively shorter term measure of performance, feeding success (Fig. 1).

\section{Predicted consumption, temperature and growth rate}

Membranipora serrilamella specific growth rate was significantly related to predicted consumption $\left(F_{1,8}=\right.$ $6.0, \mathrm{p}<0.05)$ and mean temperature $\left(F_{1,8}=18.1, \mathrm{p}<\right.$ 0.01 ) and a regression model comprising the 2 terms (full model, $F_{2,8}=11.4, \mathrm{p}<0.01$ ) explained over $79 \%$ of the variation in colony growth (tolerance values were $>0.9$, indicating no significant collinearity among the 2 independent variables). Colony specific growth rate was positively related to predicted consumption (partial correlation $=0.50$, accounting for the influence of temperature; Fig. 6a) and negatively related to mean temperature (partial correlation $=0.75$, accounting for the influence of consumption; Fig. 6b).

\section{Current speed and abundance}

The percent cover of Membranipora serrilamella on kelp blades at the end of the growth experiment varied among sites and was related to current speed (Fig. 7). Sites where flow speeds were consistently too slow (CARP, MOKI) or too fast (NAPL) for maximal feeding success were characterized by comparatively low cover of the bryozoan (Fig. 7). Cover of colonies on kelp blades at sites characterized by intermediate flows during the experiment (AQUE, MOKO) was 2- to 5 -fold greater than at sites characterized by more extreme high or low flow speeds $\left(F_{4,208}=13.6, \mathrm{p}<\right.$ 0.0001; Fig. 7). 

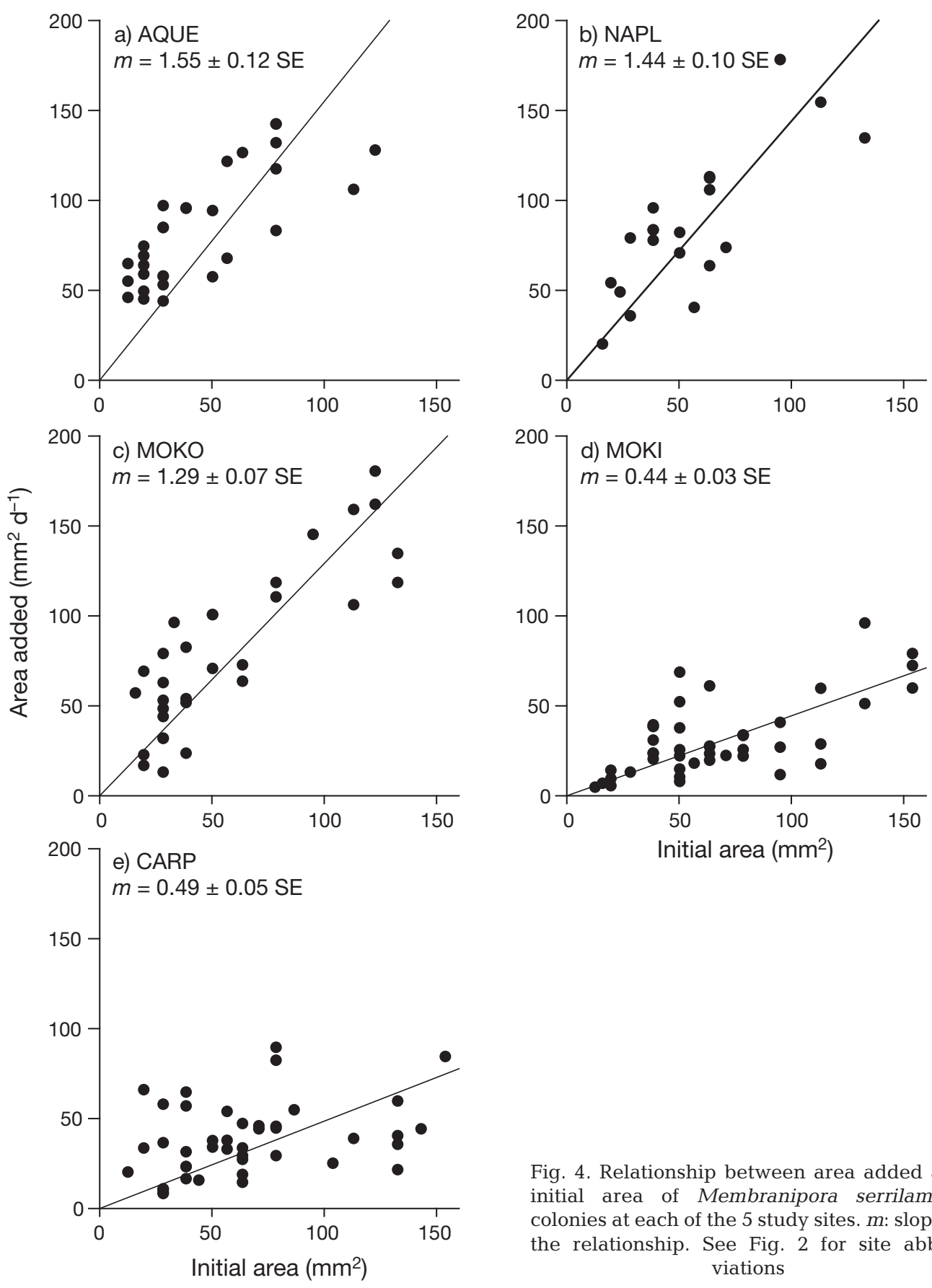

Fig. 4. Relationship between area added and initial area of Membranipora serrilamella colonies at each of the 5 study sites. $m$ : slope of the relationship. See Fig. 2 for site abbreviations

\section{DISCUSSION}

Numerous studies have investigated the influence of water flow on bryozoan feeding or growth rate, yet the vast majority has been conducted in the laboratory where colonies are exposed to a small number of constant current speeds. Such conditions may not resemble the dynamic flow environment in which communities of these suspension feeders typically occur (Denny
1988, Gaylord et al. 2007). The present study provides the first field-based evidence that ambient currents can elicit a unimodal feeding response in bryozoans and that in situ feeding and growth are positively and quantitatively related over a wide range of naturally occurring flow speeds. Results also show that growth rates and percent cover of Membranipora serrilamella colonies were correlated with ambient current speed and highest at sites characterized by intermediate 


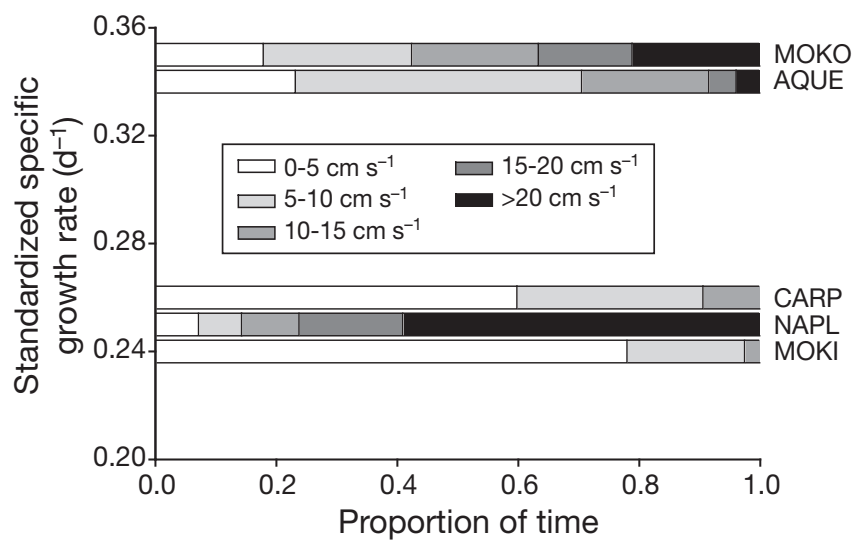

Fig. 5. Membranipora serrilamella. Average specific growth rate (adjusted for temperature) at the 5 study sites plotted against the proportion of time that 5 categories of current speed occurred at each site during the growth experiment. Categories are based on Fig. 1. See Fig. 2 for site abbreviations

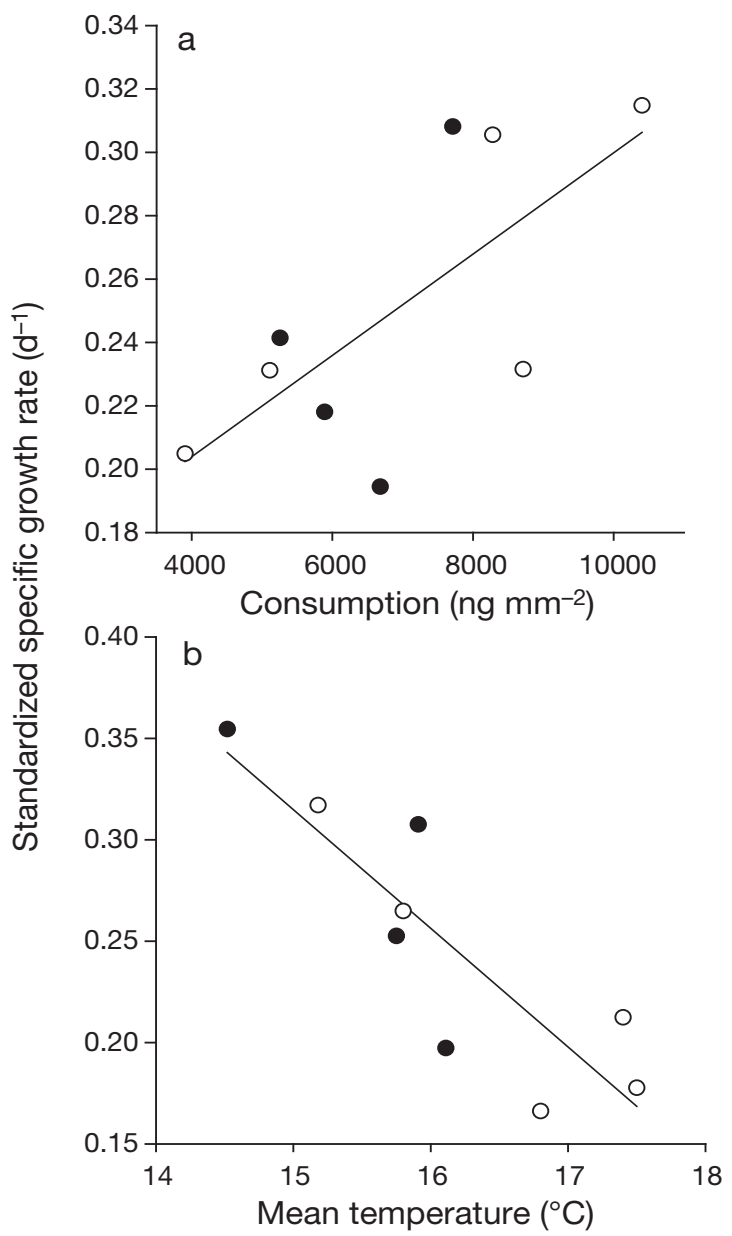

Fig. 6. Membranipora serrilamella. Standardized specific growth rate in 2006 (@) and 2007 (O) in relation to (a) predicted consumption (based on Fig. 1) after accounting for the influence of mean temperature and (b) mean temperature after accounting for the influence of predicted consumption

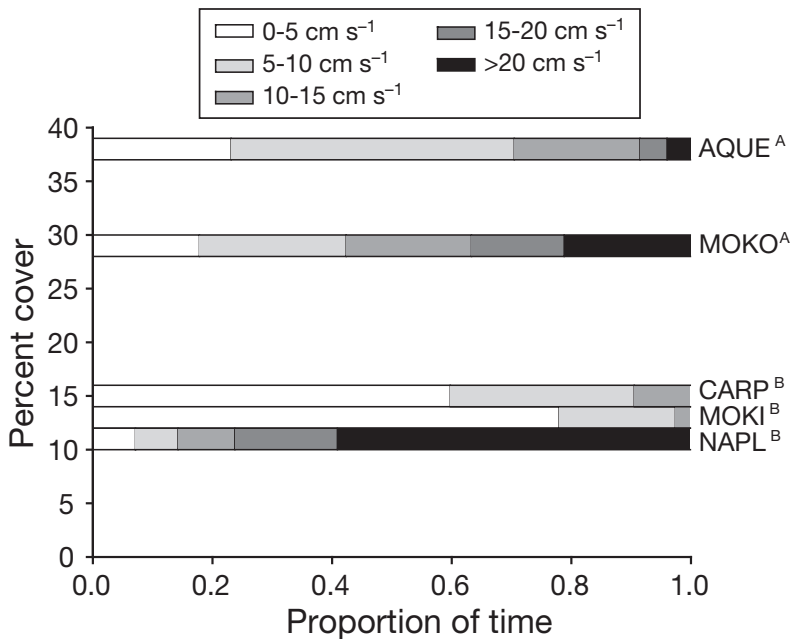

Fig. 7. Membranipora serrilamella. Average percent cover on kelp blades in relation to the proportion of time that 5 categories of current speed occurred at each site during the growth experiment. Current speed categories were chosen based on Fig. 1. Superscripted letters indicate significant differences between sites (Tukey's HSD, p < 0.05) in percent cover. See Fig. 2 for site abbreviations

flows. By integrating across levels of biological organization in the field, the present study suggests that variation in short-term feeding success can lead to spatial patterns in the growth rate and population abundance of encrusting bryozoans.

In their comprehensive review, Wildish \& Kristmanson (1997) proposed that, in general, suspension feeders exhibit a unimodal feeding response as a function of current speed. If the concentration of food particles is held constant, theory suggests that the rate of capture increases with faster currents at low flows, most likely due to a rise in particle encounter rate. Feeding then reaches a maximum at intermediate flows, after which it decreases as excessive ambient speeds interfere with capture mechanisms. Increases in current speed inhibit capture either because particles pass by too quickly to be intercepted or flows deform feeding structures. Wildish \& Kristmanson (1997) reviewed examples of a variety of taxa, including sea pens, gorgonians, crinoids and scallops, which feed most successfully at intermediate current speeds. At the time of their review, data on feeding and flow were inadequate for testing the unimodal function theory in bryozoans.

The present study and recent work by Pratt (2008) reveal that bryozoans in the genus Membranipora exhibit a form of the unimodal feeding response described by Wildish \& Kristmanson (1997). Pratt (2008) showed that Membranipora membranacea growing on glass slides in a recirculating flow tank ingested the greatest number of beads at intermediate ambient current speeds. A quadratic trend in the data 
indicated a unimodal feeding response. Pratt's (2008) work made significant advances over previous studies in that feeding was measured at 5 ambient current speeds; however, the flow treatments were at the lower range of those experienced by bryozoans living on kelps in the field. The results of the present study build on those of Pratt (2008) by demonstrating that the shape of the relationship between feeding and flow holds for a natural range of current speeds and food particles. In turn, Pratt's (2008) work lends important generality to this field-based study. For example, some evidence indicates that bryozoans may feed on bacteria (Gosselin \& Qian 2000, Winston 1977) and other non-photosynthetic organisms. The values reported here for GPC and ambient chlorophyll concentration only reflect the chlorophyll-based fraction, rather than the total amount of consumed and available food. However, it is unlikely that the unimodal shape of the relationship was the result of some bias produced by the approach I used, especially given that Membranipora spp. provided with latex beads exhibited a qualitatively similar response to increasing flow (Pratt 2008).

Another consequence of my effort to capture the effect of realistic environmental conditions on Membranipora serrilamella was that I observed feeding in high currents during just 2 sampling periods, both of which occurred at one site (MOKO). For a number of reasons, the values for feeding success during these periods can be considered independent and likely resulted from fast water flow rather than a site effect. First, the 2 high-flow observations occurred in different years (2005 and 2006), and it is unlikely that every other factor that might have influenced feeding success at MOKO was identical in both years. For example, the chl a concentration at MOKO during the highflow period in $2006\left(3.2 \mathrm{ug} \mathrm{l}^{-1}\right)$ was twice that of the 2005 period $\left(1.5 \mathrm{ug} \mathrm{l}^{-1}\right)$. Second, these concentrations were within $1 \mathrm{SD}$ of the average, indicating that the 2 high-flow values for GPC were not a function of relatively low food availability. Third, lower flow speeds (3.2 to $7.2 \mathrm{~cm} \mathrm{~s}^{-1}$ ) occurred at MOKO during other sample periods, and values for GPC (12.5 to $16.7 \mathrm{ng} \mathrm{mm}^{-2}$ ) spanned the range observed at other sites. Lastly, fast currents also occurred during $60 \%$ of the growth experiment at NAPL (Fig. 2a), where the standardized specific growth rate of $M$. serrilamella was low relative to other sites (Fig. 5). These findings suggest that fast currents and flow-mediated inhibition of feeding were not restricted to MOKO. In spite of the different set of limitations that arise in field (present study) versus laboratory settings (Pratt 2008), Membranipora spp. appear to exhibit a unimodal feeding response to flow.

The pattern of increased feeding success at incrementally higher current speeds (left side of Fig. 1) likely resulted from enhanced food availability in the vicinity of the colonies (Wildish \& Kristmanson 1997). An encrusting invertebrate, Membranipora serrilamella feeds in a zone characterized by vertical gradients in water flow and particle concentration, often referred to as the boundary layer (Denny 1988). Ambient current speed plays an important role in delivering food to sessile suspension feeders because vertical mixing and the transport of particles to regions along the substratum are enhanced at higher free-stream flows (Wildish \& Kristmanson 1979). This enhancement is important because suspension-feeding activity can deplete food levels in the boundary layer (reviewed in Wildish \& Kristmanson 1997, see Peterson \& Black 1987 for cockles, Frechette et al. 1989 for mussels, Jonsson et al. 2005 for clams), such that the amount of particles removed by filtration may not be replaced by an equivalent quantity. Subsequent refiltration of impoverished waters can then lead to reductions in the individual performance of suspension feeders. For example, the clearance rate of an encrusting bryozoan in running seawater was reduced because surrounding waters were depleted by an interspecific neighbor (Buss 1979); reduced growth and reproductive effort of infaunal clams in a lagoon off southern California were probably the result of food limitation rather than competition for space (Peterson 1982); and growth rates of mussels transplanted within a mussel bed in a small tidal gut in the St. Lawrence estuary were greater than those of mussels raised above the bed (Frechette \& Bourget 1985). Boundary layer conditions depend not only on ambient current speed, but also on bottom roughness (Wildish \& Kristmanson 1979). My findings suggest that the microscale rugosity of the kelp blades did not create sufficient vertical mixing to counteract depletion by suspension feeders in low flow conditions.

The pattern of declining feeding success at higher current speeds (right side of Fig. 1) was probably due to the deformation of Membranipora serrilamella feeding structures. Fortuitously, Eckman \& Duggins (1993) observed the behavior of $M$. membranacea lophophores exposed to a range of ambient current speeds in laboratory flumes that closely matched the range of speeds I observed in situ. The feeding structures functioned normally at flows $<14 \mathrm{~cm} \mathrm{~s}^{-1}$, were retracted at flow speeds between 14 and $18 \mathrm{~cm} \mathrm{~s}^{-1}$ and became bent (up to $45^{\circ}$ ) at flow speeds $>20 \mathrm{~cm} \mathrm{~s}^{-1}$ (Eckman \& Duggins 1993, their Table 4). The lophophores of colonies in the present study may have became similarly deformed and retracted, which would have prevented them from capturing food particles in high flow conditions and led to the observed decline in feeding success at speeds $>13 \mathrm{~cm} \mathrm{~s}^{-1}$. Faster current speeds have been shown to have negative effects on the feeding success and growth rates of other taxa, but the 
mechanisms by which these responses are governed depends on the species and the specific type of feeding structure (reviewed in Wildish \& Kristmanson 1997). For example, siphonate bivalves with an inhalant siphon oriented normal to flow may not experience inhibition, whereas ambient currents can prevent particle capture by scallops depending upon orientation to the flow (Wildish et al. 1987, Eckman et al. 1989).

Flow-mediated feeding success of Membranipora serrilamella was positively related to colony growth rate, such that when the influence of temperature was removed, predicted consumption explained $50 \%$ of the variation in growth rate among sites and years. By measuring growth along a continuous flow gradient at 5 sites and current speed throughout the duration of the study period, the results of the present study provide context for equivocal findings in the literature regarding the relationship between flow and growth rate. For instance, Grünbaum (1997) measured higher growth rates of Membranipora membranacea in the faster of 2 flow treatments $\left(1.1 \mathrm{~cm} \mathrm{~s}^{-1}\right.$ as compared with $0.3 \mathrm{~cm} \mathrm{~s}^{-1}$ ), both of which fell at the lower end of the range of flows in the present study. In contrast, Okamura \& Partridge (1999) found no difference in the growth of $M$. membranacea colonies at 2 sites characterized by fast flow $\left(8.2\right.$ to $56 \mathrm{~cm} \mathrm{~s}^{-1}$ and 41 to $86 \mathrm{~cm}$ $\mathrm{s}^{-1}$ ). However, also consistent with the present study, the growth rates of $M$. membranacea colonies were much lower and the flow speeds much faster than the values reported here or in Pratt (2008). Comparisons among studies do have to be made cautiously, as ambient levels of food availability, temperature, substrate rugosity and competition from neighbors could all influence variation in growth rate. Another potential source of variation in growth is allocation of energy to reproduction. Without data on gonad production, its influence on the observed growth rates cannot be eliminated. Yet the collection of colonies from the same source populations increases the likelihood that the pattern in colony specific growth rate I observed was not the consequence of population-level differences in allocation of energy to reproduction.

The present study provides the first field-based evidence that bryozoan feeding success translates to colony growth rate and that dynamic flow conditions have consequences for both short-term and integrated measures of individual performance. The distribution and abundance of encrusting bryozoans appear to be, at least in part, due to how flow influences feeding and growth. More research is needed to understand the interactive effects of water flow and other processes, including predation (Grünbaum 1997), space competition (Harvell et al. 1990) and recruitment (Yoshioka 1982). By showing that that in situ feeding success and growth are related, results from the present study sup- port recent theoretical and observational evidence suggesting that resource acquisition plays an important role in the evolution of sheet-like bryozoans such as Membranipora serrilamella. Sheet-like forms of encrusting colonies, with zooids packed closely together, appear to have stronger, more coordinated feeding currents that can reach farther into the foodrich water column (Okamura et al. 2001, Pratt 2004). Flow-mediated relationships between short- and longterm measures of performance and the implications for demography and morphology likely extend beyond suspension-feeding invertebrates to other marine organisms whose feeding and uptake rates are influenced by current regime (Kiflawi \& Genin 1997, Hepburn et al. 2007).

Acknowledgements. I am grateful to numerous dive buddies who shared the adventures of field work with me, but especially to A. Craig, L. Davenport and B. Doctor. I am fondly indebted to S. Harrer, C. Nelson and B. Mardian for support with all diving operations. I thank S. Anderson for help with species identification and A. Al-Humaidhi and J. Jones for their advice and extensive assistance with chlorophyll analyses. I am hugely indebted to J. Fram for providing me with all of the current speed data. Finally, I am grateful to D. Reed, S. Holbrook, R. Schmitt, M. Brzezinski, J. Samhouri, A Rassweiler and S. Lester for their advice on the manuscript and support throughout the project. Funding was provided by the National Science Foundation's Long Term Ecological Research Program (OCE-9982105, OCE-0620276), the University of California Marine Council's Coastal Environmental Quality Initiative, the UC Santa Barbara Shoreline Preservation Fund and the longtime generosity of Bruce and Susan Worster.

\section{LITERATURE CITED}

Arkema KK (2008) Consequences of kelp forest structure and dynamics for epiphytes and understory communities. PhD dissertation, University of California, Santa Barbara, CA

Burnham KP, Anderson DR (2002) Model selection and multimodel inference, 2nd edn. Springer, New York

Buss LW (1979) Bryozoan overgrowth interactions - the interdependence of competition for space and food. Nature 281:475-477

Dagg MJ, Walser WE (1987) Ingestion, gut passage, and egestion by the copepod Neocalanus plumchrus in the laboratory and in the subarctic Pacific Ocean. Limnol Oceanogr 32:178-188

Denny MW (1985) Water motion. In: Littler M (ed) Handbook of phycological methods, Vol. IV, Ecology. Cambridge University Press, Cambridge

Denny MW (1988) Biology and the mechanics of the waveswept environment. Princeton University Press, Princeton, NJ

Dick MH, Grischenko AV, Mawatari SF (2005) Intertidal Bryozoa (Cheilostomata) of Ketchikan, Alaska. J Nat Hist 39: 3687-3784

- Eckman JE, Duggins DO (1993) Effects of flow speed on growth of benthic suspension feeders. Biol Bull 185:28-41

- Eckman JE, Peterson CH, Cahalan JA (1989) Effects of flow speed, turbulence, and orientation on growth of juvenile bay scallops Argopecten irradians concentricus (Say). J Exp Mar Biol Ecol 132:123-140 
Elner RW, Hughes RN (1978) Energy maximization in diet of shore crab, Carcinus maenas. J Anim Ecol 47:103-116

Feldman GC, McClain CR (2007) Ocean Color Web, MODIS Aqua Reprocessing 1.1. NASA Goddard Space Flight Center. Available at http://oceancolor.gsfc.nasa.gov/

Frechette M, Bourget E (1985) Food-limited growth of Mytilus edulis in relation to the benthic boundary layer. Can J Fish Aquat Sci 42:1166-1170

Frechette M, Butman CA, Geyer WR (1989) The importance of boundary layer flows in supplying phytoplankton to the benthic suspension feeder, Mytilus edulis. Limnol Oceanogr 34:19-36

Fretwell SD (1972) Populations in a seasonal environment. Princeton University Press, Princeton, NJ

Gaylord B, Rosman JH, Reed DC, Koseff JR and others (2007) Spatial patterns of flow and their modification within and around a giant kelp forest. Limnol Oceanogr 52: 1838-1852

Gosselin LA, Qian PY (2000) Can bacterivory sustain survival and growth in early juveniles of the bryozoan Bugula neritina, the polychaete Hydroides elegans and the barnacle Balanus amphitrite? Mar Ecol Prog Ser 192:163-172

Grünbaum D (1997) Hydromechanical mechanisms of colony organization and cost of defense in an encrusting bryozoan, Membranipora membranacea. Limnol Oceanogr 42:741-752

Harvell CD, Caswell H, Simpson P (1990) Density effects in a colonial monoculture: experimental studies with a marine bryozoan (Membranipora membranacea L.). Oecologia 82:227-237

Hepburn CD, Hurd CL, Frew RD (2006) Colony structure and seasonal differences in light and nutrients modify the impact of sessile epifauna on the giant kelp Macrocystis pyrifera (L.) C Agardh. Hydrobiologia 560:373-384

$>$ Hepburn CD, Holborow JD, Wing SR, Frew RD, Hurd CL (2007) Exposure to waves enhances the growth rate and nitrogen status of the giant kelp Macrocystis pyrifera. Mar Ecol Prog Ser 339:99-108

Holbrook SJ, Schmitt RJ (1988) The combined effects of predation risk and food reward on patch selection. Ecology 69:125-134

Hurd CL (2000) Water motion, marine macroalgal physiology, and production. J Phycol 36:453-472

Jonsson PR, Petersen JK, Karlsson O, Loo LO, Nilsson SF (2005) Particle depletion above experimental bivalve beds: in situ measurements and numerical modeling of bivalve filtration in the boundary layer. Limnol Oceanogr 50:1989-1998

Kacelnik A (1984) Central place foraging in starlings (Sturnus vulgaris). I. Patch residence time. J Anim Ecol 53:283-299

Kiflawi M, Genin A (1997) Manipulation and the feeding rates of reef-dwelling planktivorous fish. Ecology 78:1062-1077

Kirby-Smith WW (1972) Growth of the bay scallop: the influence of experimental currents. J Exp Mar Biol Ecol 8:7-19

LaBarbera M (1984) Feeding currents and particle capture mechanisms in suspension feeding animals. Am Zool 24: 71-84

Lesser MP, Witman JD, Sebens KP (1994) Effects of flow and seston availability on scope for growth of benthic suspension-feeding invertebrates from the Gulf of Maine. Biol Bull 187:319-335

Levin PS, Coyer JA, Petrik R, Good TP (2002) Communitywide effects of a nonindigenous species on temperate rocky reefs. Ecology 83:3182-3193

Mackas D, Bohrer R (1976) Fluorescence analysis of zooplankton gut contents and an investigation of diel feeding patterns. J Exp Mar Biol Ecol 25:77-85
McPhee-Shaw EE, Siegel DA, Washburn L, Brzezinski MA, Jones JL, Leydecker A, Melack J (2007) Mechanisms for nutrient delivery to the inner shelf: observations from the Santa Barbara Channel. Limnol Oceanogr 52:1748-1766

- Milinski M, Heller R (1978) Influence of a predator on optimal foraging behavior of sticklebacks (Gasterosteus aculeatus L.). Nature 275:642-644

Okamura B (1992) Microhabitat variation and patterns of colony growth and feeding in a marine bryozoan. Ecology 73:1502-1513

Okamura B, Partridge JC (1999) Suspension feeding adaptations to extreme flow environments in a marine bryozoan. Biol Bull 196:205-215

Okamura B, Harmelin J, Jackson JBC (2001) Refuges revisited: enemies versus flow and feeding as determinants of sessile animal distribution and form. In: Evolutionary patterns: growth, form and tempo in the fossil record. Jackson JBC, Lidgard S, McKinney FK (eds) University of Chicago Press, Chicago, IL, p 61-96

Otero MP, Siegel DA (2004) Spatial and temporal characteristics of sediment plumes and phytoplankton blooms in the Santa Barbara Channel. Deep-Sea Res II 51: $1129-1149$

Peterson $\mathrm{CH}$ (1982) The importance of predation and intraand interspecific competition in the population biology of two infaunal suspension-feeding bivalves, Protothaca staminea and Chione undatella. Ecol Monogr 52:437-475

Peterson CH, Black R (1987) Resource depletion by active suspension feeders on tidal flats: influence of local density and tidal elevation. Limnol Oceanogr 32:143-166

Pratt MC (2004) Effect of zooid spacing on bryozoan feeding success: Is competition or facilitation more important? Biol Bull 207:17-27

> Pratt MC (2008) Living where the flow is right: how flow affects feeding in bryozoans. Integr Comp Biol 48:808-823

> Purcell JE, Madin LP (1991) Diel patterns of migration, feeding, and spawning by salps in the subarctic Pacific. Mar Ecol Prog Ser 73:211-217

Quinn GP, Keough MJ (2002) Experimental design and data analysis for biologists. Cambridge University Press, Cambridge

Riisgård HU, Goldson A (1997) Minimal scaling of the lophophore filter-pump in ectoprocts (Bryozoa) excludes physiological regulation of filtration rate to nutritional needs. Test of hypothesis. Mar Ecol Prog Ser 156:109-120

Rodriguez V, Echevarria F, Bautista B (1991) In situ diel variation in gut pigment contents of Ceriodaphnia sp. in stratification and destratification periods. J Plankton Res 13: 187-196

Schwaninger HR (1999) Population structure of the widely dispersing marine bryozoan Membranipora membranacea (Cheilostomata): implications for population history, biogeography, and taxonomy. Mar Biol 135:411-423

Sears MW (2005) Geographic variation in the life history of the sagebrush lizard: the role of thermal constraints on activity. Oecologia 143:25-36

> Sebens KP, Grace SP, Helmuth B, Maney EJ, Miles JS (1998) Water flow and prey capture by three scleractinian corals, Madracis mirabilis, Montastrea cavernosa and Porites porites, in a field enclosure. Mar Biol 131:347-360

Smith RC, Baker KS, Dustan P (1981) Fluorometric techniques for the measurement of oceanic chlorophyll in the support of remote sensing. Visibility Laboratory, Scripps Institution of Oceanography, University of California, San Diego, La Jolla, CA, SIO Ref. 81-17

Sogard SM, Olla BL (1998) Behavior of juvenile sablefish, Anoplopoma fimbria (Pallas), in a thermal gradient: bal- 
ancing food and temperature requirements. J Exp Mar Biol Ecol 222:43-58

Sponaugle S, LaBarbera M (1991) Drag-induced deformation: a functional feeding strategy in two species of gorgonians. J Exp Mar Biol Ecol 148:121-134

Wildish DJ, Kristmanson DD (1979) Tidal energy and sublittoral macrobenthic animals in estuaries. J Fish Res Board Can 36:1197-1206

Wildish DJ, Kristmanson DD (1997) Benthic suspension feeders and flow. Cambridge University Press, Cambridge
Wildish DJ, Kristmanson DD, Hoar RL, DeCoste AM, McCormick SD, White AW (1987) Giant scallop feeding and growth responses to flow. J Exp Mar Biol Ecol 113 207-220

Winston J (1977) Feeding in marine bryozoans. In: Woollacott RM, Zimmer RL (eds) Biology of bryozoans. Academic Press, New York

Yoshioka PM (1982) Role of planktonic and benthic factors in the population dynamics of the bryozoan Membranipora membranacea. Ecology 63:457-468

Appendix 1. Membranipora serrilamella. Colony transplantation and model selection
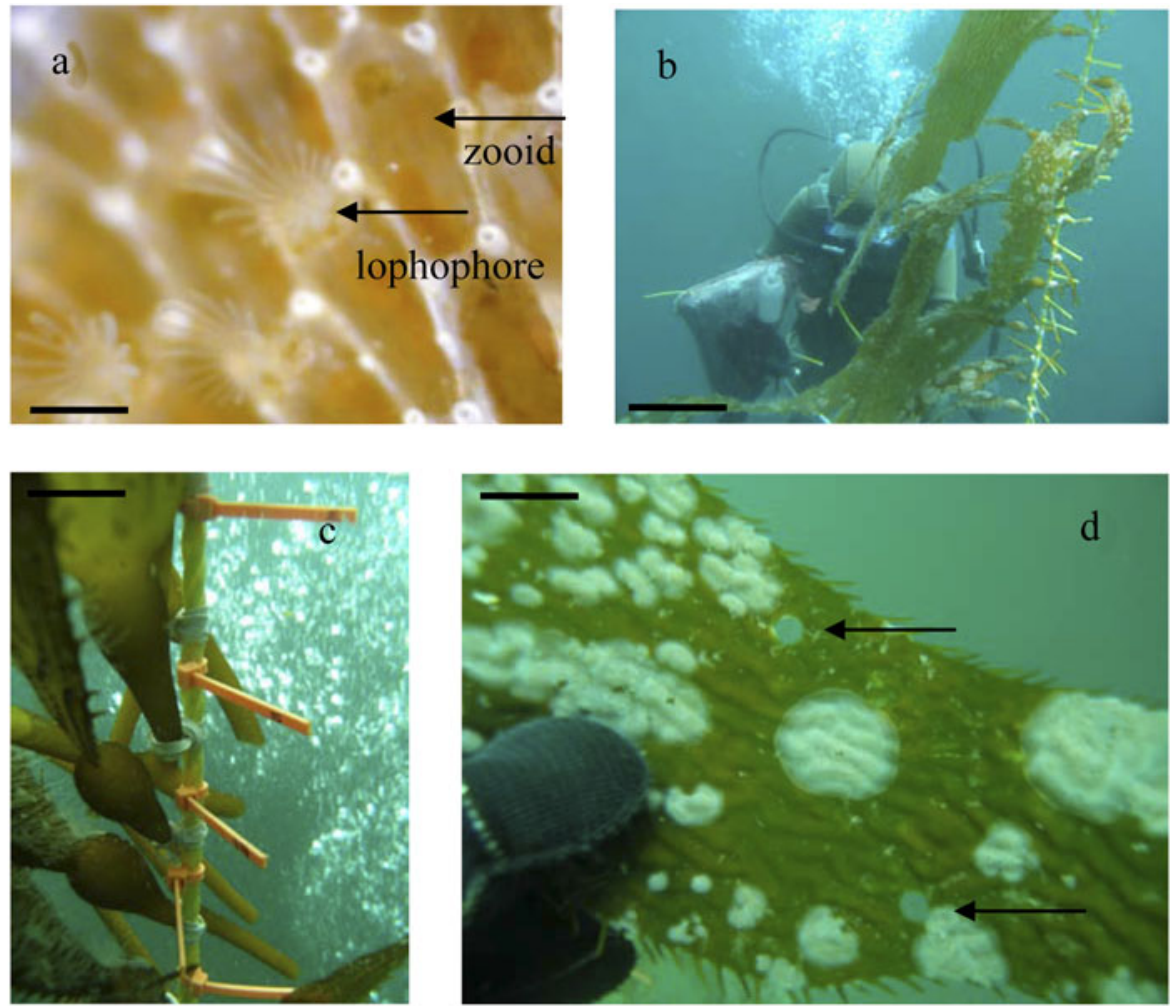

Fig. A1. Membranipora serrilamella. (a) Zooids and their feeding structures (lophophores). Scale bar $~ 0.02 \mathrm{~cm}$. (b) A diver transplanting giant kelp blades occupied by $M$. serrilamella to a polypropylene line suspended vertically in the water column. Scale bar $\sim 20 \mathrm{~cm}$. (c) Giant kelp blades attached using rubber bands and individually marked with labeled zip ties. Scale bar $\sim 3 \mathrm{~cm}$. (d) M. serrilamella colony marked with 2 hole punches (arrows) in the giant kelp blade. Scale bar $\sim 2 \mathrm{~cm}$. Photo credits: (a, c, d) K. Arkema; (b) A. Craig 
Table A1. Summary of model selection analysis comparing different functional forms for the relationship between Membranipora serrilamella feeding success and water flow. Three functional forms, linear, saturating and parabolic, were evaluated using Akaike's information criterion corrected for small sample sizes ( AIC $_{c i}$ Burnham \& Anderson 2002). Fitted parameters were flow $(X), 2$ constants $(a, b)$ in the linear and asymptotic models, 3 constants in the parabolic model $(a, b, c)$ and an error term in each model. AIC difference $(\Delta i)$ is the difference between the $\mathrm{AIC}_{\mathrm{c}}$ of model $i$ and the lowest $\mathrm{AIC}_{\mathrm{c}}$ observed. Akaike weight (wi) was calculated as the model likelihood, $\exp (-\Delta i / 2)$, normalized by the sum of all model likelihoods. Values close to 1 indicate greater confidence in the selection of a model. The parabolic model, which suggests feeding success ( $y$ ) was highest at intermediate flow speeds, was considerably superior to the other models tested.

\begin{tabular}{|llcc|}
\hline Functional form & Model & $\Delta i$ & $w i$ \\
\hline Linear & $y=a X+b$ & 4.18 & 0.08 \\
Asymptotic & $y=a X(1+b X)^{-1}$ & 2.47 & 0.21 \\
Quadratic & $y=a+b X+c X^{2}$ & 0 & 0.71 \\
\hline
\end{tabular}

Editorial responsibility: Charles Peterson, Morehead City, North Carolina, USA
Submitted: August 21, 2008; Accepted: June 3, 2009

Proofs received from author(s): July 22, 2009 